\title{
The Struggle of Hilda Doolittle to Exist as She Wants to Exist
}

\author{
Hilda Doolittle’ın İstediği Gibi Varolma Mücadelesi
}

\section{Emel ZORLUOĞLU*}

\begin{abstract}
Hilda Doolittle (1886-1961), better known by her initials H.D., for the greater part of her prolific life, was concerned about her own life story. She was criticized for repeatedly writing about her own life and pictured as a prisoner of autobiography. However, H.D. was not writing a pure autobiography. When her prose is analysed, it is clear that she preferred to write roman à clef (A French term meaning 'novel with a key', refering to fictional works in which public figures and events are disguised behind a fictional screen, Boyde 2009, 156) rather than autobiography. To understand what was missing in autobiography proper and what parchment H.D.'s modernist roman à clef was written on, I will primarily discuss how autobiography proper has been gendered in Western culture and how this genre is treated within H.D.'s modernist coterie. H.D.'s selection of the roman à clef as a genre did not spring from a strange desire to write her life, but rather, was a deliberate choice serving her own purposes. H.D. used roman à clef 'therapeutically', as a 'passive' measure to create a powerful voice. I will illustrate my thesis by juxtaposing relevant passages in her romans à clef:Asphodel, The Paint it Today and Hermione, as well as contextualizing it by using the psychoanalytic works of Nancy Chodorow on identity formation to argue that women needed a new form of expression.
\end{abstract}

Keywords: H.D., Autobiography, Roman à clef, Identity, Western Culture

Öz: H.D. kısaltması ile daha iyi tanınan Hilda Doolittle (1886-1961) hayatının büyük bölümünde kendi hayat hikâyesini kaleme almaya çalışmıştır. Yazar sürekli kendi hayatını yazmakve özyaşam öyküsünün esareti altında kalmakla suçlanmıştır. Fakat H.D. saf bir özyaşam hikâyesi yazmamaktadır. Yazıları incelendiğinde öz yaşam öyküsünün yanı sıra roman à clef yazmayı tercih ettiğini görüyoruz. Öz yaşam öyküsü yazmaktaki sorunsalları anlamak için batı kültüründe özyaşam yazımı nasıl şekillenmiş ve H.D.'nin kendi çevresinde bu yazı türü nasıl değerlendirilmiştiri ele almamız gerekmektedir. H.D.'nin roman à clef tercihi yalnızca kendi hayatını kalem alma arzusundan çıkmamıştır bu yazı türü elde etmek istediği amaçlara onu götürecek bir araçtır aynı zamanda. H.D. roman à clef tarzını terapötik bir şekilde kullanarak güçlü bir ses olarak var olmayı başarmıştır. H.D.'nin bu yazım tekniği sayesinde güçlü bir ses oluğu tezini roman à clef tarzında yazdığı Asphodel, Paint it Today ve Hermione yapıtlarından alıntıların analizi ve Nancy Chodorow’un kimlik üzerine psikanalitik teorisiyle açıklamaya çalışılacaktır.

Anahtar sözcükler: H.D., Özyaşam, Roman à clef, Kimlik, Batı Kültürü

H.D. started her writing career as an imagist poet in the tight-knit avant-garde milieu of London, mingling the ideas of Ezra Pound, the founder of Imagism with all his ‘do’s and don'ts, and T.S. Eliot, the flag-bearers of masculine modernism. In imagist poetry, Pound defended the banner of

* Öğr. Gör. Dr., Erzurum Teknik Üniversitesi, Edebiyat Fakültesi, Amerikan Kültürü ve Edebiyatı Bölümü, Erzurum.emelzorluoglu@gmail.com.

This article is developed from the unpublished PhD thesis submitted to the University of Sussex in 2017. 
Art for Art's Sake, taking it in a new direction, towards what would become New Criticism. As Max Saunders suggests, the New Criticism, following on from Eliot, devalued the autobiographical utterance as one facet of the reaction against biography because it was the quintessential Victorian genre $(2010,2)$. Critical texts such as Eliot's Tradition and the Individual Talent (1920) correspondingly highlighted the importance of being impersonal. Eliot further notes in his work that 'art may be said to approach the condition of science' $(1997,53)$. Locating modernism within the space of male science and technology equates high modernism with typically masculine terms: difficult, experimental, learned and progressive (Childs 2008, 24), a realm in which H.D. could never fit in, or rather in which she did not really want to fit in.

This new canon of classics opposed the idea that 'the history of the world is but the biography of great men' (Saunders 2010, 2), privileging reason and a masculine formalism. As Andreas Huyssen discusses in his seminal book After the Great Divide, mainstream modernism is characterised as an elitist movement involving a closed group of male writers who valorised high art as a defence against the rise of a feminised mass culture. As a corollary, 'the modernism/ mass culture dichotomy, has been gendered as masculine/feminine’ $(1986,49)$. Some forms and genres, such as autobiographic texts and letters, were concomitantly devaluated, because subjectivity, emotionality and passivity are features traditionally associated with women (Huyssen 1986, 2).

Whilst high modernist male writers often classified autobiographical texts in relation to a feminised mass culture, influential genre critics of autobiography, from Georges Gusdorf (1956) and Pascal Roy (1960) to James Olney (1980), William Spengermann (1980) and Philippe Lejeune (1989), presumed that autobiography proper requires an absolute individuality which women lack. George Gusdorf represents an extreme version of this position:

Autobiography does not develop endemically in cultures where the individual does not oppose himself to all others; he does not feel himself to exist outside of others, and still less against others, but very much with others in an interdependent existence that asserts its rhythms everywhere in the community. Lives are so thoroughly entangled that each of them has its centre everywhere and its circumference nowhere. The important unit is thus never the isolated being (1956, 29-30).

Autobiography, as a genre, thus offers an opportunity to present 'a shared social judgement of an individual's life, the hope of objective knowledge and moral certainty' (Saunders 2010, 3), by 'assuming the conflation of masculinity and humanity, canonising the masculine representative self' (Brodzki 1988, 2). Basing the understanding of autobiography on Gusdorf's argument, one cannot value women's writing, which is mostly composed of fragmented diaries, journals and notebooks reflecting their fragmented selves and lives (Jelinek 1980, 19). No wonder then that female autobiographies were often misread, marginalised or ignored completely by virtue of their being outside traditional canonical definitions of autobiography. To provide space for previously omitted women's autobiographies, feminist critics of autobiography needed to return to the territory of male autobiography so as to re-delineate its borders.

Estelle Jelinek argues that 'from earliest times, these discontinuous forms have been important to women because they are analogous to the fragmented, interrupted, and formless nature of their lives. But they also attest to a continuous female tradition of discontinuity in women's autobiographical writing to the present day' $(1980,19)$. The psychological shape of women's lives can be helpful in understanding the reasons for such a preference. Many critics of female autobiography draw heavily on Chodorow's concept of 'identification' and separation to highlight 
how the female self-forming process differs from men. Unlike Freudian concepts suggesting individualistic psychoanalytical models and attempting to explain women through castration complex, penis envy and other masculinised concepts, Melanie Klein, Luce Irigaray and Nancy Chodorow base their approach on object-relation theories and point out that women are more inclined to inter-subjectivity. According to Chodorow, the whole problem of individuation stems from the child's first love object: the mother, and the symbiosis between mother and child. She points out the difficulty the girl child experiences whilst trying to adopt a separate self since she feels that she is the same as her first love object, whilst the boy does not.

Growing girls come to define themselves as continuous with others; their experience of self contains more flexible or permeable ego boundaries. Boys come to define themselves as more separate and distinct, with a greater sense of rigid ego boundaries and differentiation. The basic feminine sense of self is connected to the world, the basic masculine sense of self is separate (Chodorow 1999, 169).

Whilst boys tend to build up firm ego boundaries through separation, girls engage in fusion to find their identity through other consciousness. The following passage from H.D.'s HERmione may better illustrate the point.

I know her. I know her. Her. I am Her. She is Her. Knowing her, I know Her. She is some amplification of myself like amoeba giving birth, by breaking off to amoeba. I am sort of mother, a sort of sister to Her. I will not have her hurt. I will not have Her hurt. She is Her. I am Her. Her is Fayne. Fayne is Her. I will not let them hurt (1984, 158, 181, emphasis added).

Through her disruptive language and oscillating use of 'her', being at the same time both object and subject, H.D. abolishes the fundamental distinction between subject and object. Building his argument on Susan Stanford Friedman and Rachel BlauDuPlessis, Travis (1987) puts forward the idea that the 'syntactical disruption' which occurs in the 'recurring phrase, 'I am Her' generates a 'proliferation of meanings' (126). H.D. conveys the fusion of two selves into one, refusing to split them. Whilst 'Her' stands for Her it also stands for Fayne (Fayne stands for her Lesbian lover; Frances). Their images are amalgamated into one single reflection. This is further supported by the image of 'amoeba', a unicellular organism that does not have a definite shape. Through projecting herself onto Frances, H.D. gets lost in a kind of fusion. There is no longer a distinction between her and Frances. It is like a return to the womb, to a state where the boundary between object and subject gets lost.

From a cultural point of view, as Rowbotham examines in Woman's consciousness, Man's world, 'the prevailing social order stands as a great and resplendent hall of mirrors. It owns and occupies the word as it is and the world as it is seen and heard' $(1973,38)$. Susan Friedman, building her discussion on Rowbotham, points out that a 'mirror does not reflect back a unique, individual identity to each living woman; it projects an image of WOMAN, a category that is supposed to define the living woman's identity' (1988, 38), as it does for men, whose mirror image reflects an image of MAN. However, whilst man's image serves to reflect 'his universality, his representativeness, his role as a spokesman for the whole community' (Brodzki $1988,1)$, woman's image of marginality, and a multi-dimensional, fragmented self-image, alienates her from being self-confident, she is made inadequate, an outsider, an 'other' (Jelinek 1986, 7). Thus, in a literary text, whilst men may tend to reflect a more coherent narrated persona, female experience is mostly reflected in less coherent forms. Expecting identical ways 
of narrating the self from both men and from women, who have different appraisals of the self, thus leads to either the objectification or marginalisation of women. A group of modernist women writers such as H.D., Anais Nin, Radclyffe Hall, Dorothy Richardson and Djuna Barnes, for example, never became leading figures in the canon by virtue of their marginalised writing style.

Concomitantly, women's experiences are seen as insignificant, hindering an affirmative sense of self. To illustrate the point, in HERmione, H.D. depicts how she fails all the conventional expectations of individuality after failing in 'an authoritarian institute of learning' (Guest 1984, 5), Bryn Mawr college. '[S] he tried to concentrate on one frayed disc of [a] green pool or mirror that would refract image. She was nothing. She must have an image no matter how fluid, how inchoate' $(1984,5)$. Hermione could not achieve any sense of herself through the masculine paradigm of separation. So, in order to be defined, she is desperately in need of another consciousness. She repeatedly reflects this continuous search in her prose. One of these many instances is portrayed in Paint it Today:

I think, as the only girl in a very large family, she wanted most passionately a girl child of her own age, a twin sister, which, in the frantic, premature passion that comes to many children at about the age of ten. She visualised poignantly and with curious desperate yearning as a very little sister, a baby sister. This particular yearning for one child, a girl of its own particular temperament, was satisfied when Midget had left school, had left childhood, girlhood; was drifting unsatisfied, hurt as baffled out of a relationship [...] (1992, 6-7).

From the age of ten, H.D. knew that defining herself through another's consciousness would let her female self-blossom. This need to define one's self through another's consciousness is not, as Mary Mason notes, a destroying but a nurturing force for the female self (1980, 210). H.D. achieves her writing self through her personal and subjective prose, enabling her to attain feminine self-achievement through both identifying herself with her 'sisters' and others, and resisting the lure of conventional language and autobiography proper.

H.D. could neither be a scientist, and write a Victorian autobiography, nor express her fragmented and shattered self through an art approaching 'the condition of science'. She therefore needed to adopt another form and preferred to write her autobiographical prose in 'the most autobiographical of autobiographical' (Saunders 2010, 8) forms: the roman à clef. Though H.D.'s 'awareness of a specifically poetic female tradition', as Friedman notes, 'was less distinct' (1986, 211), shifting from one of the most respected forms, such as impersonal poetry, to one of the most denigrated forms, such as the roman à clef, was not a stress-free choice. H.D. was, after all, as Barbara Guest suggests, 'the purest imagist of them all' $(1984,319)$. Switching from poetry to prose meant defying her male mentor, Ezra Pound and her husband, Richard Aldington, another influential canonical figure.

Both Pound and Aldington opposed H.D.'s shift from poetry to prose and harshly criticised her for doing so. Pound condemned H.D. for 'spoil[ing] the 'few but perfect positions she might have held to on', and degraded her by calling her 'utterly narrow-minded' $(1971,114,157)$. In a similar vein, Aldington attacked H.D.'s prose writing. 'Prose No, you have so precise, so wonderful an instrument why abandon it to fashion another perhaps less perfect. You have, I think either to choose pure song or else drama or else Mallarmian [sic] subtlety. Which will you choose' (Friedman, Penelope, 33)? These rhetorical questions are clear examples of H.D.'s male mentors attempting to efface and control her artistic identity. All these pleas for H.D. to remain 
perfect according to their standards is in an attempt, as DuPlessis argues, to 'return [H.D.] covertly to the status of muse, embodiment of an ideal to which others aspire, a role sacred to poetry as a social institution' $(1986,8)$. Further, as Friedman notes, memoirs like Tribute to Freud (1919-1948), Compassionate Friendship (1955) and End to Torment (1958) suggest that she saw herself as an anomaly in her immediate circle of male poet-friends: Ezra Pound, William Carlos Williams, T.S. Eliot, D.H. Lawrence and Richard Aldington (Friedman 1986, 211).

In a letter written to John Cournos on 9 July 1920 or 1921, H.D. puts into words why she needed to shift from poetry to prose.

"You are quite right about the novel and I shall certainly chuck it. But I must explain [to] you first that the novel is not intended as a work of art - at least, not as it stands. It is a means to an end. I want to clear up an old tangle. Well, I don't put my personal self into my poems. But my personal self has got between me and my real self, my real artist personality. And in order to clear the ground, I have tried to write things down - in order to think straight, I have endeavoured to write straight [...] clairvoyance is the only sanity for me.

But in the novel I am working through a wood, a tangle of bushes and bracken, out to a clearing, where I can see again" (Hollenberg 1986, 148).

The letter includes extremely significant details about H.D.'s struggle whilst finding her writing self. A deep understanding of the letter might be the key to comprehending H.D.'s suffocation and entrapment. As becomes clear, H.D. first needed to put an end to something. The question that needs to be asked here is: What? What needs to be ended is not explicitly stated, but rather obscured by the phrase 'old tangle'. We might initially turn to her traumatic past, the shattering deaths of her brother and father and her stillborn child. Another interpretation of 'old tangle' could be either an end to Ezra Pound's influence or an end to the denied fusion with her mother in a masculine world. Whatever she meant, prose was 'a means to an end'. 'Writing about the thoughts and feelings associated with traumas', James Pennebaker suggests, 'forces individuals to bring together the many facets of overwhelmingly complicated events. Once people can distil complex experiences into more understandable packages, they can begin to move beyond the trauma' $(1997,193)$. H.D. thus used her romans à clef therapeutically, to write about her chaotic past so as to understand it and release herself from its harmful psychological effects.

As H.D. states in her letter: 'the novel is not intended as a work of art' (Hollenberg 1986, 148). This is striking, that H.D. did not consider her novels to be art, even though she felt the need to write them. The supposedly 'devalued' personal novel hence becomes a bridge connecting H.D. to valued, impersonal poetry (Friedman 1990, 34). Whilst in her imagist poetry she was, at least aesthetically, tied to an impersonal view of lyric, in her prose H.D. made subjective lifewriting central. However, in her letter, H.D. does not challenge 'male' authority; therefore, she appears to be adopting a prose form wherein she builds a personal self for the sake of rebuilding an impersonal self in poetry. As also noted by Susan Friedman, 'no doubt H.D.'s letter to Cournos adapts a rhetoric of duplicitous self-effacement that reflects their different positions within the gender system' $(1990,34)$.

H.D., even if she was aware of her mentors' dominance over her, could not explicitly oppose them, but would not follow their suggestions either. Cournos was defined as an 'agent of destruction' by H.D., but he was still included in her list of seven male initiators (Hollenberg 1986, 3). Why could she not place herself outside the established truths of her close male friends? Was she too fragile? Unlike love or compassion, anger by its nature embeds isolation 
from the object which feelings target. The separation anxiety that anger generates is intolerable for most women, and H.D. is no exception. So, H.D. deliberately favours the marginalised side of the dichotomy and assumes a feminine role. The letter can be read as another palimpsest from which H.D. effaces signs of herself from its phallocentric discourse, which is dominated by signs of power. She occupies both figuratively and literally the place of the 'mother'. Though she appears as if she is not contradicting her male mentors' ideas, she will quit imagism and master herself and her past through opposing her initiators' ideals. Once she grasps the causeeffect of her traumatic past, she will be able to see beyond it. Through her writing, H.D. recognises that she needs simultaneously to be both master and slave, object and subject of her narrative.

H.D.'s letter to her female friend, Viola Jordan, however, was written in a rather different tone, one which reflects H.D.'s anger towards her male mentors attempting to control 'who H.D. is'.

"I am bringing out a volume of prose, semi-private, in Paris. No one really likes my prose much but I can't be held up by what the critics think H.D. ought to be like [...] I have a purple sex story (though highly spiritualised) about a Greek girl in Rome which I like but people don't think it quite 'worthy' of H.D. I say who is H.D.? They all think they know more about what and why she should or should not be or do than I" (Friedman 1981, 6, emphasis added).

Who is H.D.? H.D. needed to separate herself from her male mentors, Ezra Pound, and her husband, Richard Aldington. She needed to disentangle herself from what they thought 'H.D. ought to be like' so as to establish her new self/selves. Contrary to her male mentors' wishes, H.D. would quit Imagism, and fashion herself anew in her 'prose' through creating an aesthetic of the marginal in her romans à clef.

To work through her early life, H.D. picked a denigrated and neglected prose form: the roman à clef, a fusion of two other genres, autobiography and fiction. Roman à clef, a French term meaning 'novel with a key', refers to fictional works in which public figures and events are disguised behind a fictional screen (Boyde 2009, 156).Contrary to the popularity of the genre among modernist writers, the massive range of literary critics focusing on autobiography since the 1980s have remained almost entirely silent on this genre. Apart from Sean Latham's Art of Scandal, discussing roman à clef, there are only a few articles, book chapters and lines in some books that briefly refer to, but never fully elaborate, this specific genre.

It is interesting to note that the roman à clef is not even granted a place as a genre in either Sidonie Smith and Julia Watson's seminal work, Reading Autobiography (Smith 2010, 183209), in which fifty-two different genres are listed, or in the recently published Encyclopaedia of Life Writing (Jolly 2001). This negligence may arise from the fact that the genre has long been treated as a scandal sheet in which gossip is shared among coterie members (Latham 2009, 6). The roman à clef, as H. M. Paull points out in Literary Ethics: A Study in the Growth of Literary Conscience, 'is a form of art which many would like to see abandoned' (quoted in Latham 2009, 7). However, in his extensive 1888 analysis, Fernand Drujon classified writings in this genre by centuries and revealed that the genre has existed since the sixteenth century (quoted in Finn 2005, 81). This analysis further points out that each century brought with it its own way of treating this genre. The function of this genre, enabling a writer to narrate unacceptable ideas to conventional minds in a satirical or parodic way, has assured its continued usage to the present day (Finn 2005, 81-82). Latham remarks that 'this mode of writing 
nonetheless played a generative albeit unexamined role in the twentieth-century renovation of the novel, providing passage beyond Victorian realism and into a far murkier field where fact and fiction pleasurably_-and sometimes dangerously_intertwine' (2009, 7).

The roman à clef can be considered an anarchic genre by its very nature. By 'anarchy', I mean that the genre does not conform to expected patterns; it creates a new blurred fusion of autobiography and fiction, private and public. Concomitantly, 'the genre deeply troubles', as Sean Latham notes, the 'most basic assumptions about the aesthetics of fiction and the ethics of reading' $(2009,9)$. Saunders, however, hints at usage of the roman à clefform in the following words: in an epoch when most formal auto/biography narrates the lives of men, 'fiction paradoxically becomes an arena for granting female experience an equivalent reality in the public sphere. The production of fictive autobiography in such cases can be seen as an expression of a baffled desire to write autobiography, rather than a despair about the form itself' (Saunders 11). In agreement with Saunders, I claim that short-circuiting the significance of the form seems problematic within the larger frame of how women make use of it.

H.D.'s choice of an ignored form, not supported by her circle, was not without good reason. Indeed, her choice perfectly counterparts her marginal self. With her innovate usage of a particular genre, roman à clef H.D. would create a nexus wherein the same sign would blossom into a multitude of meanings H.D. manages not only to protect herself whilst being marginalised but also seek revenge against her male mentors: Pound and Aldington; and create her own female tools of expression to exist as she wants to exist.

H.D. puts heavy emphasis on protecting herself from the harsh criticism of a general audience. How otherwise could H.D. bring herself to write her novels with a subtext of lesbian love or ambivalent motherhood feelings in an era when there was a very real threat of obscenity trials, with Radclyffe Hall's fate serving as an example (Friedman 1990, 103)? With the security that is provided in the guise of roman à clef, H.D. manages to 'explore an identity that was culturally marginal' (Boyde 2009, 158). She narrates her same-sex love and offers 'a version of female sexuality which is distinct from phallocentric models and conventional notions of women as passionless and motivated solely by the drive to reproduce' (Simpson 2004, 37). The roman à clef form, as Sashi Nair's recent study asserts, provides marginalised women writers with the chance to present a desire that might otherwise be unspeakable. In Asphodel, a vivid portrayal of emotional and physical attachment is revealed when Hilda whispers 'no one will ever love you as I love you.' H.D. establishes Hermione's identity as a woman in love with another woman through her overt, repetitive and insistent language use. H.D. rebels with her extremely explicit narration:

"I, Hermione, tell you I love you Fayne Rabb. Men and women will come and say I love you. I love you Hermione, you Fayne. Men will say I love you Hermione but will anyone ever say I love you Fayne as I say it? [...] I don't want to be (as they say crudely) a boy. Nor do I want you to so be. I don't feel a girl. What is all this trash of Sappho? None of that seems real, to (in any way) matter. I see you. I feel you. My pulse runs swiftly. My brain reaches some height of delirium. Do people say it is indecent? Maybe it is. I can't hear now see anymore, people" (52-53, emphasis added).

In Wise Sappho, H.D. writes of Sappho's poetry that it is 'like a jewel, sent by the beloved' [...] 'transcending colour yet [...] containing all colour, $(1982,53)$. What does she then mean by 'What is all this trash of Sappho?'? This might confuse the reader, for it seems to be the 
opposite of Woolf's thinking back through mothers. It is just that the H.D. character is, at this point in the novel, rejecting the language of literature for the body ('I see you, I feel you'). She might be seen to be rejecting language, for the body, but from another perspective she may be valuing Sappho's 'trash'. When one scrutinises the word 'trash', one can start to see through the word. The Oxford Dictionary defines 'trash' as a 'North American' word meaning 'waste material/ refuse' or 'cultural items, ideas, or objects of poor qualit'y. 'H.D.'s persona', as this reference to a Collecott's quotation suggests, 'in London circa 1911, falls back on an Americanism to express her sense of being something different' $(1999,82)$. In the symbolic order, there is no room for foolish talk; equally, the social order perpetuates itself by discharging whom and what does not meet its requisites, just as the human body excretes and discards unwanted matter (Collecott 1999, 82). The trash of Sappho reads like Kristevan abject; unless you are initiated, you will not be able to crack the code and see through it. With the use of abject metaphors, along with their apparent opposites: jewels, gems and pearls, H.D. creates a language of desiring the female body and encodes her homoerotic desires within it, as both precious and discarded. To illustrate this further, in Paint it Today, H.D. laments how she and her lover have been pulled apart:

"It was natural that she and Josepha (and such as she and Josepha) lived isolated, clarid, separate, distinctive lives in America. That was natural. It was natural that she and Josepha and such as she and Josepha should be cast out of the mass of the living, out of the living body, as useless as natural wastage, excrementitious, it is true, thrown out of the mass, projected forth, crystallized out, orient pearls, to stand forever after, a reflection somehow, on the original rasped and wounded parent" (98, emphasis added).

Here again, Kristeva's abject surfaces. H.D. equates herself and Josepha (Frances) to 'natural wastage', 'excrementitious', which can be connected to both birth and lesbian desire. Through repetition of 'she and Josepha (and such as she and Josepha)' twice in the same paragraph, H.D. asserts that she and Josepha are one of many SHE and Josepha couples. Once again, she manages to evoke the palimpsest layering of the eternal story of marginalised women. There is ironic repetition of how 'nature' 'works to undermine the stigmatisation of women artists and lesbian lovers as unnatural' (Simpson 2004, 49). 'The existing systems are incapable of recognising the value of women lovers-artists and the worth of their creativity' (Simpson 2004, 49). Being 'orient pearls' casts them into the margins of Western society, 'as useless as natural waste'. H.D.'s obsessive use of gems and pearls shows 'an awareness that the meaning of the body, and of the female body in particular, is far from single, 'natural' and fixed. The meanings and associations of pearls and gems are mobile, proliferating, pearls themselves are palimpsestic in structure and gems multi-faceted' (Simpson 2004, 38).

With the veiled narration that is provided in roman à clef, H.D. also manages to take her revenge on her male contemporaries. In the roman à clef, the author does not only want to narrate or fictionalise her own life, she also wants to portray some public figures in whatever way she sees fit. Though the thin disguise may hide the public figures from the general public, it certainly does not hide them from the coterie. The coterie is able to discern information in texts which to the unknowing reader potentially remains obscure or hidden without the key (Boyde 2009, 156). Even if the real persons behind the noms de plume are discovered, we can never be certain to what extent H.D.'s account is accurate. In any fictionalised work, particularly in her romans à clef, we read the events as H.D.'s fantasising mind wished to interpret them. 
Recreating a persona in the realm of the imagination and having the power to treat him/her in a way that pleases the author, in a way s/he might not have done in real life, overlaps with H.D.'s struggles with always being at the nexus of passive and aggressive. This recalls the identification theory of Chodorow, in which 'girls come to define themselves as continuous with others', so they tend to ally with a person rather than separate themselves from that person. In her letter, H.D. stated that she 'couldn't afford to make enemies'. This does not, however, seem to be the case in H.D.'s romans à clef, where she takes her revenge on Ezra Pound by describing his individual idiosyncrasies and divulging nuanced details between them. Whilst in Paint it Today, George, the surrogate for Ezra Pound, is depicted as a 'hectic, adolescent, blundering, untried, mischievous and irreverent male youth (7), in HERmione, he is portrayed as a 'harlequin', 'piglike' and 'a great tawny beast, a sort of sub-lion pawing at her' $(65,85,147)$.

\section{Conclusion}

H.D. rejects the formalistic parameters of her male contemporaries by writing in the blurry boundary of romans à clef. Neither fiction nor truth, this genre became the best form in which she could explore and be reborn. As she writes in Paint it Today:

"She, Midget, did not wish to be an eastern flower painter. She did not wish to be an exact and over-précieuse western, a scientific describer of detail of vein and leaf of flowers, dead or living, nor did she wish to press flowers and fern fronds and threads of pink and purple seaweed between the pages of her book. Yet she wanted to combine all these qualities in her writing and to add still another quality to these three. She wished to embody, as this other quality, the fragrance of the flowers" (1992, 17).

Throughout her childhood, H.D. was affected by her biologist grandfather and her astronomer father; however, as she perfectly describes in this passage, she does not want to look through these double lenses of reason - she wants to add her feelings, her sensations, the fragrance of flowers. She does not want to be either Western or Eastern. As Sara Ahmed and others have argued, whilst thought and reason are associated with masculine and Western subjects, emotions and bodies are identified with femininity and the Eastern racial other (2004, 170).This also embodies a desire for a palimpsest - to be able to write several different contrasting things over each other but not invalidating any of them. By combining all these qualities, she sought to generate a new creative medium: an amalgam of science and art, East and West, mother and father, science and religion, fact and fiction.

H.D. fashioned roman à clef whilst vehemently refusing to write an 'honest' autobiography of her life when she was asked by Viking Press (Friedman 1990, 69). Roman à clef provided H.D. with the tools she needed to create a text according to her own values. This narrative method for H.D. was an end to the power control, a realisation that the power of Sappho's poetry does not come from being objective, impersonal or difficult - qualities valued by modernists like Hulme and Eliot (Boebel 1997, 24). Roman à clef not only offered H.D. all that was denied to ‘women' writers, but also met H.D.'s expectation by not accommodating any art expectation of her time. It was an amalgam of real and imaginary, a limbo state where the reader will never know how much of it is 'real'.This genre disturbs the boundaries between the real persona and the fictionalised; thus it shatters any assumed reality and reflect that there is never one single reality but rather multiple connotations. It was the best form for H.D. to challenge male authority and give an account of her 'real' feelings. 


\section{REFERENCES}

Ahmed S. (2004). Cultural Politics of Emotions. New York 2004.

Boebel D. (1997). “The Sun Born in a Woman: H.D.'s Transformation of a Masculinist Icon in 'The Dancer”. Eds. E. J. Harrison \& S. Peterson, Unmanning Modernism: Gendered Re-readings (1997) 14-30. Knoxville.

Boyde M. (2009). "The Modernist Roman à Clef and Cultural Secrets, or I Know That You Know That I Know That You Know”. Australian Literary Studies 24/3-4 (2009) 155-166.

Brodzki B. \& Schenck C. (1988). Life/Lines: Theorizing Women’s Autobiography. New York 1988.

Childs P. (2008). Modernism. London 2008.

Chodorow J. N. (1999). The Reproduction of Mothering: Psychoanalysis and the Sociology of Gender. California 1999.

Collecott D. (1999). H.D. and Sapphic Modernism 1910-1950. Cambridge 1999.

DuPlessis B. R. (1986). H.D.: The Career of That Struggle. Brighton 1986.

Eliot T. S. (1997). "Tradition and the Individual Talent". The Sacred Wood: Essays on Poetry and Criticism (1997) 39-49. London.

Finn R. M. (2005). "Imagining Rachilde: Decadence and the Romans à Clef”. French Forum 30/1 (2005) 81-96.

Friedman S. S. (1981). Psyche Reborn: The Emergence of H.D. Bloomington 1981.

Friedman S. S. (1986). "Gender and Genre Anxiety: Elizabeth Barrett Browning and H.D. as Epic Poets". Tulsa Studies in Women's Literature 5/2 (1986) 203-228.

Friedman S. S. (1988). “Women’s Autobiographical Selves: Theory and Practice”. Ed. S. Benstock, The Private Self: Theory and Practice of Women's Autobiographical Writings (1988) 34-62. London.

Friedman S. S. (1990). Penelope's Web: Gender, Modernity, H.D. 's Fiction. Cambridge 1990.

Guest B. (1984). Herself Defined. New York 1984.

Gusdorf G. (1956). "Conditions and Limits of Autobiography”. Ed. J. Olney, Autobiography: Essays Theoretical and Critical (1980) 28-48. Princeton.

H.D. (1926). HERmione. London 1984.

H.D. (1982). Notes on Thought and Vision and Wise Sappho. San Francisco 1982.

H.D. (1992). Asphodel. Durham 1992.

H.D. (1921). Paint it Today. New York 1992.

Hollenberg D. K. (1986). "Art and Ardor in World War One: Selected Letters from H.D. to John Cournos”. The Iowa Review 16/3 (1986) 126-155.

Huyssen A. (1986). After the Great Divide: Modernism, Mass culture, Postmodernism. Indianapolis 1986.

Jelinek E. C. (1980). “Women's Autobiography and Male Tradition”. Ed. E. C. Jelinek, Women's Autobiography: Essays in Criticism (1980) 1-38. London.

Jelinek E. C. (1986). The Tradition of Women's Autobiography: From Antiquity to the Present. Boston 1986.

Jolly M. (2001). Encyclopaedia of Life Writing: Autobiographical and Biographical Forms. London 2001.

Latham S. (2009). The Art of Scandal: Modernism, Libel Law, and the Roman à Clef. Oxford 2009.

Lejeune P. (1989). On Autobiography. Minneapolis 1989.

Mason M. (1980). “The Other Voice: Autobiography of Women Writers”. Ed. M. Mason, Autobiography: Essays Theoretical and Critical (1980) 207-235. Princeton.

Olney J. (1980). "Autobiography and the Cultural Moment: A Thematic, Historical, and Bibliographical Introduction”. Ed. J. Olney, Autobiography: Essays Theoretical and Critical (1980) 3-27. Princeton.

Pennebaker W. J. (1997). Opening Up: The Healing Power of Expressing Emotions. New York 1997.

Pound E. (1971). The Selected Letters of Ezra Pound, 1907-1941. New York 1971.

Rowbotham S. (1973). Woman's Consciousness, Man's World. London 1973.

Roy P. (1960). Design and Truth in Autobiography. Cambridge 1960.

Saunders M. (2010). Life-Writing, Autobiografiction, and the Forms of Modern Literature. Oxford 2010. 
Simpson K. (2004). "Pearl-diving: Inscriptions of Desire and Creativity in H.D. and Woolf”. Journal of Modern Literature 27/4 (2004) 37-58.

Smith S. \& Watson J. (2010). Reading Autobiography: A Guide for Interpreting Life Narratives. London 2010. Spengermann W. C. (1989). The Forms of Autobiography: Episodes in the History of a Literary Genre. New Haven 1980.

Travis S. (1987). “A Crack in the Ice: Subjectivity and the Mirror in H.D.’s HER”. Sagetrieb 6/1 (1987) 123-140. 